\title{
Paulina Piątek
}

Uniwersytet im. Adama Mickiewicza w Poznaniu

\section{Publicysta w sporach dzienników opinii w Polsce. Analiza felietonów Rafała Ziemkiewicza w „Rzeczpospolitej”}

\section{WPROWADZENIE}

7 BADAŃ przeprowadzonych przez Związek Kontroli Dystrybucji Prassy wynika, że w pierwszym kwartale 2010 r. liderem segmentu opinii wśród ogólnopolskich dzienników była „Gazeta Wyborcza”, wydawana przez Agorę. Średnia sprzedaż ogółem tego dziennika wyniosła 310.855 egz. Za „GW” uplasowała się „Rzeczpospolita”, lecz choć zajęła drugie miejsce, to sprzedała 116.766 egzemplarzy, tj. niemal 200 tys. mniej niż lider ${ }^{1}$. Ta tendencja stale się utrzymuje. Analogiczne badania, przeprowadzone w czerwcu 2010 r., pokazują, że pomimo generalnego spadku sprzedaży dzienników w Polsce, to właśnie „GW” na rynku tytułów opiniotwórczych radzi sobie najlepiej, ustępując jednak tabloidom $^{2}$. Na medialnym rynku coraz większą popularnością cieszą się nowe formy i treści przekazu elektronicznego, toteż gazety tradycyjne, zarówno w wydaniu drukowanym, jak i internetowym walczą o przetrwanie. Rywalizacja pomiędzy dwoma czołowymi dziennikami ma charakter nie tylko rynkowy, zwłaszcza że poza wynikami sprzedaży, wydawnictwa różni linia redakcyjna. Podczas gdy „Rz” można określić jako gazetę prawicową, „GW” ma raczej profil lewicowy, a jej redaktor naczelny należy niewątpliwie do grona wiodących postaci polskiej lewicy. Redakcje, a zatem i redaktorzy w nich piszący, tworzą swoistą opozycję3, spierającą się stale i poprzez spór zabiegającą o czytelnika.

\footnotetext{
${ }^{1}$ Sprzedaż dzienników, http://www.bankier.pl/wiadomosc/Sprzedaz-wiekszoscidziennikow-spadla-w-I-kwartale-2137626.html, 15.05. $2010 \mathrm{r}$.

${ }^{2}$ Związek Kontroli Dystrybucji Prasy podał, że podczas gdy „GW” sprzedała 319.937 egz., to jej główny, segmentowy rywal - „Rz”, w analogicznym okresie, tylko 141.692 egz. Sprzedaż dzienników, www.wirtualnemedia.pl/artykul/spadla-sprzedaz-dziennikownajwiecej-stracila-gazeta-wyborcza, 8.10.2010 r.

${ }^{3}$ Zgodnie ze Stownikiem języka polskiego, opozycja to sprzeciw, przeciwstawianie się. W określeniu słownikowym pojawia się też wzmianka o negatywnym zabarwieniu wystąpienia, stanowiska opozycyjnego. W. Doroszewski (red.), Stownik języka polskiego, t. V, Warszawa 1963, s. 1049.
} 
Różnice ideowe między „GW” i „Rz” wyraźnie wybrzmiewają w tekstach czołowych publicystów, którzy w swoich publikacjach nierzadko stosują zabiegi perswazyjne i manipulacyjne ${ }^{4}$, dyskredytując autorów z redakcji opozycyjnej. Taka postawa niejednokrotnie skutkuje zanikiem obiektywizmu, obejmującego zdaniem Jorgen Westersthala następujące komponenty: rzeczowość, na którą składają się ważność i prawdziwość oraz bezstronność, czyli kombinacja neutralności i równowagi ${ }^{5}$. Zachowanie obiektywizmu jest szczególnie trudne w sytuacji walki o przetrwanie na rynku medialnym, zwłaszcza że dziennikarze zdają sobie sprawę z mocy sprawczej językowych zabiegów perswazyjno-manipulacyjnych ${ }^{6}$.

Zaangażowanie dziennikarzy polskich dzienników opinii w walkę z konkurencyjnymi tytułami niewątpliwie wymaga pogłębionych badań. $\mathrm{Z}$ tej przyczyny postanowiono przeanalizować zbiór felietonów

${ }^{4}$ Zdaniem W. Pisarka, perswazja to „proces świadomego namawiania, nakłaniania, przekonywania kogoś do czegoś lub odradzania komuś czegoś, polegający na wykorzystaniu argumentacji słownej, a więc wykluczający użycie siły. (...) Istotą skutecznej wypowiedzi perswazyjnej jest wytworzenie u odbiorcy przekonania przechodzącego w działanie, które odpowiada interesowi perswadującego". Manipulacja to natomiast „zabieg polegający na świadomym, zręcznym, zwykle nieuczciwym skłonieniu adresata do nabrania przekonania lub podjęcia działania pozornie we własnym interesie, które de facto odpowiada interesom manipulatora (...) Stosowana przez czas długi i konsekwentnie może doprowadzić do trwałej zmiany znaczeń poszczególnych słów i wyrażeń, w ich użyciu publicznym, bądź też usunięcia z niego słów, których znaczeń nie dało się zmodyfikować”. W. Pisarek, Stownik terminologii medialnej, Kraków 2006, s. 116, 144.

${ }^{5}$ W. Adamczyk, Zasada obiektywizmu w pracy dziennikarskiej, [w:] Prasa dawna i wspótczesna, red. B. Kosmanowa, t. 3, Poznań 2002, s. 101-102.

${ }^{6} \mathrm{O}$ silnym wpływie mediów na społeczeństwo pisał Carl Hovland. Był on jednym z twórców modelu teorii uczenia, zgodnie z którą media permanentnie oddziaływają na widzów, indoktrynując ich. Przy czym pamiętać należy o polityce wewnątrzredakcyjnej, w myśl której mamy do czynienia ze swoistą „kulturą newsroomu”. L. A. Day nazwał tak zbiór norm i zasad, obowiązujących w danej redakcji, który narzuca dziennikarzom określony styl pisania: „poszczególne redakcje są mikrospołecznościami, małymi wspólnotami, każda reprezentuje pewne wzorce zachowań, pewną moralność i pewną etykę”. Pisanie o „pewnej etyce” i „pewnej moralności” pozwala uznać te wartości za relatywne. Poszczególne tytuły niewątpliwie różnią się między sobą kulturą pisania. Rzecz w tym, by przekonać odbiorcę, że lansowane podejście jest jedynym słusznym. Rzetelne podejście do tematu lub chociażby pozór takiego zachowania, z pewnością przyczyniają się do zwiększenia wiarygodności samego dziennikarza, który w oczach audytorium urasta do roli uczciwego i kompetentnego komentatora rzeczywistości. Jak twierdził Marshall McLuhan: „Tendencyjność każdego medium komunikacji jest znacznie bardziej zniekształcająca niż celowe kłamstwo (...) Wszystkie media istnieją po to, aby skłaniać nas do sztucznego sposobu postrzegania świata i narzucać nam arbitralne wartości”. To właśnie w tych poczynaniach, mających na celu wykreowanie często pseudorzeczywistości, dziennikarze uciekają się m.in. do środków perswazji i manipulacji. 
Rafała Ziemkiewicza, regularnie pisującego felietony w „Rz”. W toku analizy przebadano felietony ukazujące się w wersji drukowanej „Rz”, jak i w wersji elektronicznej, od czerwca 2007 do grudnia 2009 r. Badając je, starano się ustalić, czy, a jeśli tak to przy użyciu jakich technik perswazyjno-manipulacyjnych, Rafał Ziemkiewicz stara się zwalczać nie tylko poglądy dziennikarzy „GW”, lecz również samą „GW”.

Rafał Ziemkiewicz zaczynał karierę dziennikarską jako felietonista tygodnika „Najwyższy Czas!”, pisma o profilu konserwatywno-liberalnym. Pisał też w „Gazecie Polskiej”, tytule prawicowym, piszącym głównie o nieprawidłowościach wykrywanych we wszystkich sferach życia publicznego. Autor do dziś hołduje wartościom konserwatywnym, czego dowodem jest jego biografia. R. Ziemkiewicz działał w Unii Polityki Realnej oraz w Wydziale Prasowym stanowych struktur Partii Republikańskiej w Seattle oraz w jej Krajowym Biurze Kongresowym w Polsce. Prawicowy charakter ma również prowadzony przez niego „Antysalon Ziemkiewicza”, emitowany w TVP Info oraz „Pojedynek”, w którym R. Ziemkiewicz konfrontuje swoje poglądy z poglądami Sławomira Sierakowskiego, redaktora naczelnego „Krytyki Politycznej”. Wierny światopoglądowi prawicowemu pozostaje też $\mathrm{w}$ felietonach publikowanych w „Rzeczpospolitej”. W tym dzienniku prawicowość R. Ziemkiewicza niejednokrotnie wyrażała się w ostrej krytyce „GW” oraz jej czołowych redaktorów, z Adamem Michnikiem na czele. Antypatie dziennikarza, w tym głęboka niechęć do dziennikarzy „GW” są znane zwłaszcza po publikacji szeroko komentowanej książki Michnikowszczyzna. Zapis choroby.

W okresie od czerwca 2007 r. do końca roku 2009, na stronie internetowej „Rz” łącznie ukazało się 399 felietonów R. Ziemkiewicza. $\mathrm{Z}$ tego aż w 69 znajdujemy istotne z punktu widzenia badania odniesienia do „GW”. Biorąc pod uwagę ogólną tematykę poruszaną w tekstach przez autora, należy zauważyć, że liczba ta jest stosunkowo duża. Zwłaszcza, jeśli pamięta się, że felieton ma dotyczyć spraw aktualnych i bieżących oraz ukazuje się tak w wydaniu drukowanym, jak i na oficjalnej stronie ogólnopolskiego dziennika. Okazuje się zatem, że kwestie dyskredytujące rynkowego konkurenta często i w sporej mierze wyparły publicystykę na tematy polityczne i społeczne. Należy przypuszczać, że ten sposób R. Ziemkiewicz odpowiadał na zapotrzebowanie odbiorców „Rz”, czytanej głównie przez ludzi o poglądach prawi- 
cowych, konserwatywnych, niechętnych jednocześnie kulturze lewicy, z którą kojarzona jest „GW”.

\section{ETYKIETY}

ChARAKTERYZujĄC „GW” oraz jej redaktorów, R. Ziemkiewicz często stosował wyraziste, niekiedy bardzo ostre etykiety ${ }^{7}$ I tak w sierpniowym tekście z 2007 r. felietonista określił „GW” jako „trybunę wykształciucha”, którą w dodatku charakteryzuje „wsteczny rozwój formacji umysłowej”, mający się przejawiać ślepym dążeniem do odsunięcia od władzy „strasznych ludzi”. W opinii R. Ziemkiewicza, w porównaniu z innymi pismami „Wyborcza” wypada słabo: „Miejsce, gdzie normalne gazety zamieszczają poważne analizy i odredakcyjne komentarze, trybuna wykształciucha oddała sfrustrowanemu artyście, rozwodzącemu się o «twarzy dziecka i piskliwym głosiku ministra»". ${ }^{9}$ Ponadto felietonista określił ludzi „Wyborczej” jako „Salon”, który kieruje się bezwzględnymi zasadami lojalności wobec głównych prądów ideologicznych i samego przywódcy. Zdaniem R. Ziemkiewicza, Tomasz Jastrun z tego grona został wykluczony i teraz szuka drogi powrotu. Ponadto Salon jakoby właśnie udzielał amnestii, co jednak potwier-

${ }^{7}$ Jak pisał M. Kochan, ta „nienawistna kategoria pojęć” niewiele znaczy, ale zawsze źle się kojarzy. Wyolbrzymienie poglądów przeciwnika i skojarzenia ich z powszechnie negatywnie ocenianymi cechami lub pojęciami sprzyja porzuceniu przez odbiorcę punktu widzenia lansowanego przez atakowanego. M. Kochan, Pojedynek na słowa, Kraków 2006, s. 161-167.

${ }^{8}$ R. A. Ziemkiewicz - blog Rzeczpospolitej, Jak odsunąć strasznych lu$d z i$, http://blog.rp.pl/ziemkiewicz/2007/o8/28/powaga-na-twarzy, 2.05.2010 r. W: R. A. Ziemkiewicz - blog Rzeczpospolitej, Wołanie z kotta, http://blog.rp.pl/ziemkiewicz/2007/10/25/wolanie-z-kotla, 3.05.2010 r. znajdujemy inną etykietę. Odnosząc się do lokalizacji tak „GW”, jak i siedziby całej Agory, Ziemkiewicz nazwał redaktorów „chłopcami z Czerskiej”. Podobnie w lutowym tekście Zagłuszacze, http://blog.rp.pl/ ziemkiewicz/2008/02/o3/zagluszacze, 4.05.2010 r., w którym R. Ziemkiewicz, choć pisał głównie o sprawach z pogranicza polityki i wymiaru sprawiedliwości, to w odniesieniu do nierzetelnych praktyk dziennikarskich przywołał „GW” jako przykład. Ta, zdaniem R. Ziemkiewicza, zalicza się do mediów, które „świadomie i interesownie, podejmują decyzje o medialnym zagłuszaniu rzeczywistych problemów i odwracaniu uwagi wyborców".

${ }^{9}$ Ibidem. Przy czym mowa jest o polityku Prawa i Sprawiedliwości - Zbigniewie Ziobrze.

${ }^{10}$ Jak odsunąć..., op. cit. Za: W. Łysiak, Rzeczpospolita kłamców: Salon, Warszawa 2004. W książce „różowym salonem” określa się pejoratywnie środowiska polityczne, medialne, artystyczne i prawnicze, wywodzące się z lewicowej części opozycji PRL, które popierały politykę tzw. „grubej kreski”, rozumianej jakoby jako wyrozumiałość wobec byłych działaczy komunistycznych. Za głównego przedstawiciela tego grona autor uznaje Adama Michnika. 
dza, że jest to klika wartościująca zjawiska i wymierzającej karę ${ }^{11}$. Inne określenia, przy pomocy których R. Ziemkiewicz charakteryzował pracowników Agory, to: „Towarzystwo” ${ }^{12}$, „żołnierze wolności” ${ }^{13}$, czy„wierni, podręczni funkcjonariusze Wyborczej” oraz „podwładni oblewający gnojem "oszalałych lustratorów»"14. Felietonista etykietował także redagujących teksty w „GW” oraz jej czytelników. W „Lepperze wykształciuchów” parodiował sylwetkę zwolennika „Gazety”, którego uosobieniem miał być Adaś Miauczyński z Dnia Świra - popularnej i lubianej, polskiej komedii: „To sfrustrowany nieudacznik, który bezustannie klnie i bluzga, nie potrafiąc dostrzec, jaki jest żałosny. To symbol, w którym najpełniej odnajduje się polski inteligent" ${ }^{15}$. Z kolei dziennikarzy Wyborczej miała wyróżniać dysfunkcja, nazwana „analfabetyzmem funkcjonalnym"16. Sprowadza się on do niepojmowania lektur, a w przypadku redaktora Pawłowskiego nie jest to „chwilowe osłabienie koncentracji, ale trwała niezdolność rozumienia prostego tekstu" ${ }^{17}$.

${ }^{11}$ Ibidem. W tekście, jako tego, któremu wybaczono w ramach salonowej amnestii, wskazano Włodzimierza Czarzastego. Spełnił on funkcję antyautorytetu - był powszechnie znany jako „zły charakter” w tzw. Rywingate, w której, zdaniem sejmowej komisji śledczej, należał do „Grupy trzymającej władzę”.

${ }^{12}$ R. R. A. Ziemkiewicz - blog Rzeczpospolitej, Trzy satysfakcje, http://blog.rp.pl/ ziemkiewicz/2008/o6/24/trzy-satysfakcje, 8.05.2010 r.

${ }^{13}$ R. A. Ziemkiewicz - blog Rzeczpospolitej, Żolnierze wolności z Wyborczej, http:// blog.rp.pl/ziemkiewicz/2008/o6/22/zolnierze-wolnosci-z-wyborczej, 8.05.2010 r. Tytuł nawiązuje do wydawanego w PRL-u „Żołnierza Wolności” - gazety Ludowego Wojska Polskiego, w której na porządku dziennym, jak podał R. Ziemkiewicz, były manipulacje, konfabulacje i kłamstwa. Porównanie tu uczynione sugeruje zatem, że "GW” wyznaje dokładnie te same standardy profesjonalizmu, co „Żołnierz Wolności”.

${ }^{14}$ R. A. Ziemkiewicz - blog Rzeczpospolitej, Bezczelność Michnika, http://blog. rp.pl/ziemkiewicz/2009/04/26/bezczelnosc-michnika,zapis z 9.05.2010 r. W felietonie Przedwyborczy kociokwik, http://blog.rp.pl/ziemkiewicz/2009/o5/30/przedwyborczy-kociokwik, 9.05.2010 r. pojawiły się posiłkowe określenia dziennikarzy „GW”, określanych mianem „michnikowych dyżurnych” oraz „cyngli zatrudnionych przed wyborami na 120 proc. do strugania z bambusa jakichś afer, którymi można by obciążyć PiS”. Z kolei w tekście: Myślozbrodnia, http://blog.rp.pl/ziemkiewicz/20o8/11/11/ myslozbrodnia, 9.05.2010 r., pojawia się wzmianka o „ciotkach - przyzwoitkach z Wyborczej”. W tym felietonie R. Ziemkiewicz ironizował, że Gazeta kłamie celowo w publikowanych statystykach, ponadto ,jak zwykle udaje, że troszczy się o przyszłość prasy opiniotwórczej w ogóle. Przy czym najbardziej wydaje się troszczyć o «Rzeczpospolitą»".

${ }^{15}$ R. A. Ziemkiewicz - blog Rzeczpospolitej, Lepper wykształciuchów, http://blog. rp.pl/ziemkiewicz/2009/o1/18/lepper-wyksztalciuchow, 9.05.2010 r.

${ }^{16}$ R. A. Ziemkiewicz - blog Rzeczpospolitej, Funkcjonalny Pawłowski, http://blog. rp.pl/ziemkiewicz/2008/o1/31/analfabetyzm-funkcjonalny, 4.05.2010 r.

${ }^{17}$ Ibidem. 


\section{PostaĆ LIDERA}

NALEŻY PODKREŚLIĆ, że na wizerunek składa się wiele elementów. W tym, na kształtowanie się wizerunku gazety, wpływa odbiór jej czołowych redaktorów, czy lidera którym w „GW” jest bez wątpienia jej redaktor naczelny Adam Michnik. O A. Michniku R. Ziemkiewicz pisywał tak często, że Tomasz Lis zarzucił felietoniście „Rz” wręcz monotematyczność, o czym ten ostatni pisał w felietonie z listopada $2007 \mathrm{r}$. We wzmiankowanym tekście R. Ziemkiewicz odpierał zarzut, jakoby faktycznie cierpiał na „obsesje”, która sprowadza się do „frustracji i nienawiści do Adama Michnika"18. Nie przytaczał jednak merytorycznych argumentów, komentował jedynie rzekome przewinienia T. Lisa: „Każdy może sprawdzić, że Michnik i jego salon zajmują w moim pisaniu pięć razy mniej miejsca, niż w felietonach Lisa Jarosław Kaczyński i PiS, o których pisze on, oczywiście, z tak modną dziś miłością"19. W ten sposób zastosował technikę erystyczną, określoną przez M. Kochana jako „zmiana tematu”" ${ }^{20}$. Zabieg jest zamierzony, gdy jedna ze stron zbacza z głównego wątku, by uniknąć niewygodnej kwestii, która pojawiła się w trakcie dialogu.

Natomiast w tekście Sprawa dystynkcji R. Ziemkiewicz zastosował kombinację ironii oraz metafor retorycznych. Wykorzystał zatem sąd T. Jastruna, który oceniał książkę R. Ziemkiewicza jako perfidną, gdyż przeinaczającą wypowiedzi zwolenników A. Michnika. Odnosząc się do tej oceny, R. Ziemkiewicz ironizował i wykorzystywał zarazem „odwrócenie argumentu - retorsio argumenti” ${ }^{21}$. Twierdził, że T. Jastrun niesłusznie „perfidią” nazwał zabieg polegający na cytowaniu „wyłącznie ludzi Michnikowi życzliwych”. Chodziło bowiem nie o szacunek dla nich oraz utożsamianie się z nimi, by korzystać z ich popularności. Celem było wyśmianie, a także udowodnienie tezy, „że Michnika wystarczająco kompromitują opinie i relacje jego przyjaciół, wrogów cytować już nie trzeba”22 . Zdaniem R. Ziemkiewicza, zwo-

${ }^{18}$ R. A. Ziemkiewicz - blog Rzeczpospolitej, Moralista Tomasz Lis, http://blog. rp.pl/ziemkiewicz/2007/11/26/moralista-tomasz-lis, 3.05.2010 r.

${ }^{19}$ Ibidem.

${ }^{20}$ M. Kochan, op.cit. [w:] A. Schopenhauer, Erystyka czyli sztuka prowadzenia sporów, Warszawa 2008, s.32. Chwyt ten nazwany został „zmianą przedmiotu sporu”, czyli mutatio controversiae.

${ }^{21}$ Szerzej pisali o tym zabiegu: M. Kochan, op. cit., s. 134-137, a także A. Schopenhauer, op. cit., s. 35-36.

${ }^{22}$ R. A. Ziemkiewicz - blog Rzeczpospolitej, Sprawa dystynkcji, http://blog.rp.pl/ ziemkiewicz/2007/06/20/sprawa-dystynkcji, 1.05.2010 r. R. Ziemkiewicz znalazł się wśród nieprzyjaciół Michnika, opublikowanych na specjalnej liście, zebranej przez 
lennicy redaktora naczelnego „GW” przyjmują rolę jego wyznawców, a ich bezkrytycyzm wobec przewodnika duchowego jest karykaturalny ${ }^{23}$. Ponadto R. Ziemkiewicz określił A. Michnika jako kogoś „o niewiarygodnym tupecie i poczuciu bezkarności”"24, a także konfrontował

"GW". Felietonista skomentował to w felietonie Trzy satysfakcje, zwracając uwagę, że na liście znaleźli się także komuniści - wcześniejsi zwolennicy Michnika, którzy jednak ten status utracili, bo „mu kiedyś zaszkodzili w wewnętrznych porachunkach Towarzystwa”. R. Ziemkiewicz podkreślając swoją odrębność i fakt wpisania go na listę nieprzyjaciół naczelnego, starał się wykazać zarazem marność osób, które znalazły się na liście michnikowych sprzymierzeńców. W opinii felietonisty „Rz”: „Znaleźć się, nie daj Boże, na liście przyjaciół Michnika - obok Jaruzelskiego, Kiszczaka, Urbana, Maleszki i innych - to byłby przecież wstyd straszliwy".

${ }^{23}$ Stanowisko swoje R. Ziemkiewicz zilustrował wypowiedzią Wojciecha Maziarskiego, dziennikarza „Newsweeka”. W tekście Psycholog amator, http://blog.rp.pl/ ziemkiewicz/2008/10/14/psycholog-amator, 8.05.2010 r., felietonista "Rz” twierdził, że Maziarski zalicza się do grona dziennikarzy, którym nie mieści się w głowie, iż „wyroki oberguru można kwestionować z jakiegokolwiek innego powodu niż wrodzona podłość wynikająca z brzydkich uwarunkowań psychologicznych”. Podobnie rzecz miała się jakoby z Czesławem Kiszczakiem, o czym R. Ziemkiewicz pisał w felietonie Człowiek honoru i porządni ludzie, http://blog.rp.pl/ziemkiewicz/2009/11/21/czlowiek-honoru-i-porzadni-ludzie, 9.05.2010 r. W opinii R. Ziemkiewicza należy mówić o kulcie A. Michnika: „Zawsze wygląda to tak samo. Udaje się dorwać mikrofonu komuś, kto pyta, co robił szef Wyborczej w archiwach bezpieki, czego tam szukał i co znalazł. Sala, wypełniona «tą lepszą częścią polskiej inteligencji» zaczyna buczeć, tupać i ubliżać pytającemu, który natychmiast traci mikrofon, a Michnik z wyżyn sceny śmieje się i oznajmia: to wszystko bzdury! Nigdy nie byłem w archiwach bezpieki! Nigdy nie było żadnej «komisji Michnika»”. Tymczasem, według R. Ziemkiewicza, z zeznań Cz. Kiszczaka przyjaciela A. Michnika - wynika, że deklaracje Michnika w tym zakresie są fałszywe.

${ }^{24}$ R. A. Ziemkiewicz - blog Rzeczpospolitej, Bezczelność Michnika, http://blog. rp.pl/ziemkiewicz/2009/04/26/bezczelnosc-michnika, 9.05.2010 r. W felietonie List o salonowych frajerach, www.www.rp.pl/artykul/246082.html, 9.05.2010 r., R. Ziemkiewicz opisał naczelnego „GW” jako osobę owładniętą fobią wyszukiwania wrogów, opozycjonistów. Pisał, że zdaniem A. Michnika, „zagrożenia dla demokracji nie minęły, i trzeba się nadal przeciwstawiać”. Ponadto felietonista przytoczył kwestię powtarzaną jakoby przez pracowników „GW”, która ma ponoć, według R. Ziemkiewicza, tłumaczyć ich stosunek do ich szefa: „Michnik jest wielki, nieomylny i siedział w więzieniu”, co jednak nie jest, w myśl kąśliwej uwagi felietonisty „Rz”, wystarczającą gwarancją nieomylności. W tym samym tekście R. Ziemkiewicz przedstawił „GW” jako zagrożenie dla młodych pokoleń, które przyciąga A. Michnik. Zgodnie z sądem R. Ziemkiewicza, Gazeta „ludziom w młodym wieku uniemożliwia rozwój, co oznacza po prostu konieczność wyłączenia najpierw mózgu, a potem sumienia, co wielu przychodzi łatwo”. Motyw wspomnianego, bezrefleksyjnego poddaństwa dziennikarzy „GW” R. Ziemkiewicz wykorzystał także w tekście Zty smak, http://blog.rp.pl/ziemkiewicz/2008/12/14/ zly-smak, 9.05.2010 r., gdzie twierdził, że nie zważając na racje i fakty, piszą oni „do zadanej przez pracodawcę objętości”. Dało to wrażenie zaślepienia i bezrefleksyjnego wykonywania woli naczelnego. Na potwierdzenie swych tez, R. Ziemkiewicz pisał, że pracownicy A. Michnika „wolą być z nim, niż przeciw niemu, z Michnikiem pleść androny, niż jego wrogom sekundować w mówieniu rzeczy mądrych oraz wolą się z Michni- 
go zarówno z Tadeuszem Rydzykiem²5, jak i z Jarosławem Kaczyńskim oraz przyrównywał do Józefa Stalina ${ }^{26}$. Pisząc o A. Michniku i jego pozycji w polskim dziennikarstwie, felietonista „Rz” chętnie tworzył neologizmy, które z uwagi na oryginalność, miały szansę zapaść w pamięć czytelników. Zachowanie jednego z dziennikarzy „Tygodnia Powszechnego", który wyłamał się z linii redakcyjnej pisma i pisał negatywnie o poważanym w redakcji A. Michniku R. Ziemkiewicz określił ironicznie jako „myślozbordnię”. Pisał alegorycznie ${ }^{27}$ : „Jeden z redaktorów (...) usiłował przemycić myślozbrodnię, że troszkę jednak coś z tym Michnikiem jest nie tak i młodzi go nie rozumieją, a nie rozumiejąc, nie poważają (...) tygodnikowe autorytety wykazały się czujnością i przez kilka następnych numerów ustawiały młodziaka na baczność, wyjaśniając, że Michnika wszyscy rozumieją, słuchają i wielbią, tak było i będzie zawsze, «paniał?!»"28.

kiem mylić niż wbrew niemu mieć rację”.

${ }^{25}$ R. A. Ziemkiewicz - blog Rzeczpospolitej, Ostoja oświecenia w morzu polskiej ciemnoty, http://blog.rp.pl/ziemkiewicz/2008/o2/12/ostoja-oswiecenia-w-morzu-polskiej-ciemnoty, 4.05.2010 r. Zdaniem R. Ziemkiewicza, Rodzina Radia Maryja upatruje w T.Rydzyku mędrca i interpretatora świata. A. Michnik natomiast to przywódca Salonowej sekty, która paraliżuje środowiska, także dziennikarskie, - „wyznawców, dających się doprowadzać do spazmów histerii”. Konkluzja felietonu prowadzi do wniosku, że do grona ubezwłasnowolnionych wyznawców, zaliczają się też czytelnicy „GW”.

${ }^{26}$ R. A. Ziemkiewicz - blog Rzeczpospolitej, Z krainy pijaru, http://blog.rp.pl/ ziemkiewicz/2008/03/11/z-krainy-pijaru, 4.05.2010 r.. W tym felietonie R. Ziemkiewicz odniósł się do wydrukowanej w „GW” żartobliwej, politycznej karykatury Stalina i Jarosława Kaczyńskiego, krótko pointując, że jeśli chodzi o kult jednostki, to podobieństwo jest zauważalne. Zachodzi ono jednak nie między Stalinem i J. Kaczyńskim, lecz między Stalinem i A. Michnikiem.

${ }^{27} \mathrm{~W}$ ujęciu K. Szymanka, alegoria to rozbudowana metafora w postaci obrazowego opisu. Powstaje ona poprzez nadanie nowego znaczenia opisowi zjawisk, zdarzeń, osób, rzeczywistych lub fikcyjnych postaci. Alegoreza, to objaśnienie alegorii, dokonywane jest przez autora, lub pozostawiona domyślności odbiorcy; polega na wskazaniu odpowiedniości pomiędzy przedstawionymi w opisie elementami wraz z wiążącymi je relacjami a obiektami i relacjami rzeczywistymi. Alegoreza jest możliwa dzięki stosowaniu konwencjonalnych, ustalonych przez tradycję literacką, religijną itp. symboli. K. Szymanek, Sztuka argumentacji, Warszawa 2001, s. 21.

${ }^{28}$ R. A. Ziemkiewicz - blog Rzeczpospolitej, Zaraza $w$ Grenadzie, http://blog. rp.pl/ziemkiewicz/2007/07/13/zaraza-w-grenadzie, 1.05.2010 r. Wewnątrzredakcyjną dyscyplinę i sposób działania R. Ziemkiewicz charakteryzował również w felietonie Policjanci $i$ złodzieje, http://blog.rp.pl/ziemkiewicz/2008/o9/07/policjanci-i-zlodzieje, 8/05.2010 r. Użył w nim porównania do orwellowskiej rzeczywistości. Twierdził, że niektórzy działacze z dawnych lat zostali „po orwellowsku «wyparowani», do tego stopnia, że pokoleniu wychowanemu na mądrościach Gazety Wyborczej nic dziś ich nazwiska nie mówią”. W tym samym felietonie R. Ziemkiewicz zarzucił A. Michnikowi, że naczelny „GW” tworzy historię od nowa, a według niej jedynie on sam, Wałęsa, Kuroń 
W grudniu 2007 r. felietonista „Rz” opublikował tekst Mister Bluzg, który rozpoczął ironiczną odezwą do czytelników. Konstatował w niej: „Wiem, że sprawiam zawód swym mniej i bardziej prominentnym nieprzyjaciołom od serca, od dawna już nie pisząc niczego nowego o Adamie Michniku”29. Kpił zarazem: „wyczerpałem temat. A raczej temat wyczerpał się sam"30, a ponadto twierdzil, że odpowiedzialność za liczne ataki pod adresem A. Michnika ponosi sam atakowany, ponieważ przysporzył „Polsce więcej szkód niż całe RSW Prasa - Książka - Ruch” ${ }^{31}$. Ponadto R. Ziemkiewicz określał A. Michnika jako „ideologa PRLbis”, który z antykomunistami konsekwentnie walczy „bronią nienawiści” ${ }^{2}$. W „Licencji na demaskowanie” pojawiła się z kolei nowa konstrukcja słowna, tj. „lex Michnik”33, zawierająca sugestię że

i Geremek walczyli o wolną Polskę, „innych zaś albo nie było, albo - jak «terroryści z Solidarności Walczącej» i «nacjonaliści» z opozycji niepodległościowej - wręcz powstaniu wolnej Polski przeszkadzali”.

${ }^{29}$ R. A. Ziemkiewicz - blog Rzeczpospolitej, Mister Bluzg, http://blog.rp.pl/ziemkiewicz/2007/12/30/mister-bluzg, 3.05.2010 r.

${ }^{30}$ Ibidem.

${ }^{31}$ Ibidem. Mowa o Robotniczej Spółdzielni Wydawniczej Prasa - Książka - Ruch, która była największym koncernem wydawniczym w Europie Środkowo-Wschodniej, dotowanym przez PZPR i pozostającym na jego usługach. W tym samym felietonie R. Ziemkiewicz nazwał A. Michnika „stojakiem na zaszczyty”, po czym uciekł się do przewrotnego sposobu dyskredytacji bohatera, pisząc: „Bardzo przepraszam, ale naprawdę nic o nim napisać nie potrafię. Ale skoro sam nie potrafię, to zawsze jeszcze mogę zacytować”. W dalszej części felietonista „Rz” podkreślił, że Stefan Niesiołowski nazwał A. Michnika „typowym fanatykiem nienawiści i agresji (...) który reprezentuje rodzaj fanatyzmu, którym najbardziej się brzydzę, ponieważ pod pozorami troski o człowieka, o wolność, o demokrację lansuje twardą antykościelną, antypolską linię polityczną”. Zarzut pozoranctwa, wypowiedziany nawet przez S. Niesiołowskiego, zwłaszcza w odniesieniu do podstawowych wartości narodowych, z pewnością nie mógł przysporzyć A. Michnikowi zwolenników. I choć felieton napisany był przede wszystkim przeciwko tytułowemu „Misterowi Bluzgowi” czyli S. Niesiołowskiem, to nie sposób oprzeć się wrażeniu, że w tekście R. Ziemkiewicz sprawnie dyskredytował również A. Michnika.

${ }^{32}$ R. A. Ziemkiewicz - blog Rzeczpospolitej, Po latach, http://blog.rp.pl/ziemkiewicz/2008/09/09/po-latach, 8.05.2010 r.

${ }^{33}$ R. A. Ziemkiewicz - blog Rzeczpospolitej, Licencja na demaskowanie, http:// blog.rp.pl/ziemkiewicz/2009/o3/24/licencja-na-demaskowanie, 9.05.2010 r. W „Sądy wybuczenia warte” R. Ziemkiewicz skrytykował decyzję polskiego sądu, który skazał oskarżonego za to, że ten nazwał A. Michnika „zaciekłym obrońcą agentów”. Zdaniem R. Ziemkiewicza, „to kolejne kompromitujące polski wymiar sprawiedliwości kuriozum”. A. Michnik, zdaniem autora, urósł do „postaci groteskowej”, dziennikarza lubującego się w sądowym tłumieniu krytyk. Jak napisał felietonista: „Orzecznictwo, zgodnie z którym nie wolno nazwać przestępcą sprawcy przestępstwa, pedofilem - konesera pedofilskiej pornografii, a agentem bądź kapusiem człowieka, który był zarejestrowany jako tajny współpracownik SB lub wywiadu, stanowi obrazę zdrowego rozsądku”. Ponadto dwukrotnie, bo w Kpić się odechciewa i w Rozdane, więc sprzedane R. Ziem- 
naczelny „GW” ignoruje normy tworzone przez państwo i samostanowi własne prawo. Jedno z głównych założeń tego prawa jakoby brzmi, że A. Michnika: „nie wolno streszczać własnymi słowami ani oceniać - wolno go tylko pieczołowicie cytować” 34 .

\section{3. $\mathrm{MY}-\mathrm{ONI}$}

W ZARAZIE W GRENADZIE z lipca 2007 r. R. Ziemkiewicz twierdzil, że żyjemy „W czasach wojennych, kiedy zewsząd rozlega się krzyk, że trzeba się jasno opowiedzieć po właściwej stronie, a opowiedziawszy się, być jej zdyscyplinowanym żołnierzem" 35 . W felietonie zastosował argumentację, w której wykazywał, że społeczeństwo polskie dzieli się według znanego wzorca „my - oni”. Deklarując, że stoi po stronie obywateli, krytykował partykularyzm i szerzący się, jego zdaniem, klientelizm. W felietonie „Dlaczego lubimy nie lubić Kaczyńskich” ${ }^{6}$ z grudnia 2008 r. zauważył natomiast, że posiadanie wspólnego wroga jednoczy ${ }^{37}$. Przeciwnicy łączą się na zasadzie wspólnoty niechęci i fali krytyki wobec z góry określonej grupy lub osoby. Tak jego zdaniem jest również w przypadku Salonu, z którym ze względu na nienawistną postawę jego reprezentantów, nie można szukać kompromisu i zgody. W felietonie z lutego 2008 r. R. Ziemkiewicz formułował zarzut, że środowiska Salonowe mianują się jedyną słuszną inteligencją na kraj: „To przypomnienie, po co istnieje GW: po to, by być ostoją oświecenia w morzu napierającej zewsząd polskiej ciemnoty"38. W mniemaniu felietonisty „Rz” Salon wyróżniał tylko „swoich”, a ponieważ wśród nich ludzi godnych wyróżnień trzeba było „ze świecą szukać”39, dochodziło do absurdalnych wyborów spośród „salonowców”. Budując kontrast, R. Ziemkiewicz zestawiał praktyki nagradzania stosowane w „GW” z praktykami znanych i cenionych, zagranicznych tytułów,

kiewicz oskarżył A. Michnika o marnotrawienie pieniędzy Agory. Stwierdził, że jej problemy finansowe biorą się z pokrywania kosztów procesów naczelnego.

${ }^{34}$ Ibidem.

${ }^{35}$ R. A. Ziemkiewicz - blog Rzeczpospolitej, Zaraza..., op. cit.

${ }^{36}$ R. A. Ziemkiewicz - blog Rzeczpospolitej, Dlaczego lubimy nie lubić Kaczyńskich, www.rp.pl/artykul/9157,235281.html, 9.05.2010 r. W felietonie R. Ziemkiewicz deklarował: „Jedyną odpowiedzią na ich knowania pozostaje zaś wiara w to, że zdrowa część narodu okaże się odporna na medialną manipulację, względnie przejrzy po jakimś czasie na oczy, konfrontując propagandę z rzeczywistością".

${ }^{37}$ R. A. Ziemkiewicz - blog Rzeczpospolitej, Żotnierze wolności z Wyborczej, op. cit.

${ }^{38}$ R. A. Ziemkiewicz - blog Rzeczpospolitej, Ostoja..., op. cit.

${ }^{39}$ R. A. Ziemkiewicz - blog Rzeczpospolitej, Komu wolno krytykować Tuska, http:// blog.rp.pl/ziemkiewicz/2007/12/11/komu-wolno-krytykowac-tuska, 3.05.2010 r. 
jak np. „Time”40, w którym w jego opinii, ludzi honoruje się według kryteriów obiektywnych. W listopadzie 2007 r. pisał: „Nic nie poradzę, że żyjemy w państwie quasi-feudalnym, podzielonym na grupy branżowe i korporacje, obdarowane rozmaitymi przywilejami, zazdrośnie strzeżonymi” ${ }^{41}$. Sugerował też jakoby redakcja „GW” występowała w roli rzecznika „wtajemniczonych elit”42. Obronę Lecha Wałęsy

${ }^{40} \mathrm{~W}$ felietonie Coś $w$ umyśle, http://blog.rp.pl/ziemkiewicz/2008/10/26/cos-w-umysle, 9.05.2010 r., autor przywołał z kolei francuski dziennik „Le Monde”. W opinii R. Ziemkiewicza, historyków piszących dla tego periodyku, „GW” na swoich łamach dyskredytowała, krytykując ich próby rozgrzebywania polskiej przeszłości, która zresztą środowisku Wyborczej nie jest na rękę. Chcąc zobrazować „logikę” działań ludzi Salonu, Ziemkiewicz cytował amerykańskiego pisarza, Kurta Vonneguta: „Salon to coś w umyśle (...) to mózg podobny do zegara z wypiłowanymi trybami, który o ósmej sześć przeskakuje na dwunastą, potem cofa się do dziewiątej i nie widzi w tym nic dziwnego”. Podkreślił również, że w ramach grupowania i identyfikacji społecznej, Salonowcy „samym instynktem głupoty rozpoznają się wzajem, rozumieją się wspólnym językiem i obyczajem”, tworząc zamkniętą klikę o wątpliwej chwale. Podobne odniesienie do mediów zachodnich, znalazło się w tekście Ostoja. Tam R. Ziemkiewicz napisał, że zachodni medioznawcy, „uznaliby za krzyczący błąd w sztuce (...) prowadzenie polemiki $G W$ samej ze sobą", a także w felietonie Mister Tusk, gdzie te cuda, 8.05.2010 r. W tym ostatnim tekście publikacje „GW” zostały przeciwstawione artykułom ukazującym się w branżowych pismach zagranicznych, tym razem jest to „Financial Times”. R. Ziemkiewicz podkreślił, że w przeciwieństwie do „GW”, zachodnie gazety „nie znają tego zabobonnego lęku przed naruszeniem czci premiera”.

${ }^{41}$ R. A. Ziemkiewicz - blog Rzeczpospolitej, Moralista Tomasz Lis, op. cit. R. Ziemkiewicz powtórzył kwestię o tych uprzywilejowanych, a powtarzanie, jako jedna z technik perswazji, przekonuje i utwierdza odbiorcę w lansowanym przekonaniu. O podziale i nieporozumieniach pomiędzy otoczeniem A. Michnika, a Grupą Trzymającą Władzę, Ziemkiewicz pisał też w: Zagłuszacze, op. cit.

${ }^{42}$ R. A. Ziemkiewicz - blog Rzeczpospolitej, Moralista Tomasz Lis, op. cit. Autor wielokrotnie zwracał uwagę, jak otoczenie, skupione wokół A. Michnika relatywizuje postępowanie uczestników polskiej opozycji z czasów PRL-u. W felietonie Oszczerca Czuchnowski i sprawa stanu wojennego, http://blog.rp.pl/ziemkiewicz/2008/10/27/ oszczerca-czuchnowski-i-sprawa-stanu-wojennego-cd, 9.05.2010 r. Ziemkiewicz demaskował pozorny brak zgody Gazety na czczenie sprawców stanu wojennego. R. Ziemkiewicz na podstawie przeprowadzonych przez siebie quasi-naukowych badań wykazywał, jak często i w jakim tonie „GW” faktycznie pisała o dramatycznych obliczach komunizmu. Zredagował zatem ironiczną «złotą jedenastkę», w której zgrupował publikacje „GW" w ogóle traktujące o wydarzeniach z tamtego okresu, przy czym sam dokonał ich oceny: wśród 11 tekstów sklasyfikował „1 ostrą polemikę, ale w liście do redakcji, 3 niezłe reportaże (w tym 1 z dodatku lokalnego) o ofiarach z kopalni Wujek - przypomnijmy: ofiarach najlepiej znanych, o których nie da się zapomnieć, 1 tekst miałki, 2 teksty, w których sporo prawdy miesza się jednak z kłamstwem lub przeinaczeniem i 4 teksty skandaliczne”. Jednocześnie wyliczył artykuły, w których rozmawiano z decydentami wprowadzającymi stan wojenny, a także z A. Michnikiem - najczęściej były to teksty z pierwszych stron „GW”. Wskazał też na kwestie, które pomimo ich ważności w Gazecie potraktowano marginalnie, dla przykładu: ze wszystkich informacji, tylko 1 dotyczy- 
na łamach Gazety w czerwcu 2008 r. nazwał „propagandową wojną”, a dziennikarstwo ją propagujące - „gadzinowym”43. Przy okazji obchodów rocznicy wydarzeń sierpniowych w roku 2008, R. Ziemkiewicz zwrócił uwagę, że „GW” relacjonując uroczystości, uzurpowała sobie prawo występowania w roli rzecznika obywateli. Ponadto jakoby wespół z nimi szydziła z Buczących karłów reakcji. Zdaniem felietonisty „Rz”, krytyka pod adresem protestujących dowodziła hipokryzji dziennikarzy „GW”, którzy przez lata prowokowali potępiane zachowania. R. Ziemkiewicz konstatował: „Gazeta, tak się teraz nieposiadająca z oburzenia, przez lata robiła więcej niż ktokolwiek inny, by ludzie tacy właśnie, jak ci, którzy co roku przychodzą na groby powstańców, czuli się w Polsce upokorzeni, odrzuceni, by byli pozbawieni głosu i mogli tylko buczeć" 44 . We wrześniu wrócił do sprawy sierpniowych uroczystości w felietonie „Kto posiał wiatr”. Przytoczył w nim po raz kolejny tezę jakoby Polskę toczyła groźna choroba, nawiązując do tytułu książki swojej książki - „Michnikowszczyzny”. Wrócił również do wielokrotnie powtarzanego przez niego sądu, że podział społeczeństwa nie dokonał się sam: „mądrzej byłoby się zastanowić, kto ustanowił taki podział społeczeństwa, na «lepszych», którym należy się wszystko i «tłuszczę» pozbawioną innego głosu, niż gwizdy. (...) Kto zdeprawował polską debatę publiczną, nasycił ją taką agresją i pogardą dla przeciwnika"45. W kolejnym felietonie, z listopada 2009 r., R. Ziemkiewicz stwierdzil, że zachowania dziennikarskie redaktorów, nacechowane wrogością i pogardą, można przyrównać do zachowań subkultury kibiców: „Gdy więc publicysta Gazety Wyborczej wzywa płomiennie, by przychodzić na lewacką kontrdemonstrację «z kamieniami w kieszeniach» - jest źle ${ }^{46}$. Jednocześnie felietonista „Rz” sformułował chętnie ponawiany przez niego zarzut, w myśl którego ludzie „GW” kierują się „moralnością Kalego” 47 z sienkiewiczowskiego „W pustyni i w puszczy”

ła Jerzego Karwackiego - pracownika poznańskich Zakładów Przemysłu Metalowego im. Hipolita Cegielskiego, którego po przesłuchaniu na komisariacie MO znaleziono martwego na Os. Lecha. W tym samym czasie w Gazecie ukazało się aż 14 artykułów autorstwa Cz. Kiszczaka.

${ }^{43}$ R. A. Ziemkiewicz - blog Rzeczpospolitej, Żotnierze wolności z Wyborczej, op. cit.

${ }^{44}$ R. A. Ziemkiewicz - blog Rzeczpospolitej, Buczace karty reakcji, http://blog. rp.pl/ziemkiewicz/2008/o8/o5/buczace-karly-reakcji, 8.05.2010 r.

${ }^{45}$ R. A. Ziemkiewicz - blog Rzeczpospolitej, Kto posiat wiatr, http://blog.rp.pl/ ziemkiewicz/2008/09/02/kto-posial-wiatr, 8.05.2010 r.

${ }^{46}$ R. A. Ziemkiewicz - blog Rzeczpospolitej, Kuroń w grobie się przewraca, http:// blog.rp.pl/ziemkiewicz/2009/11/15/kuron-w-grobie-sie-przewraca, 9.05.2010 r.

${ }_{47}$ Argument Kalego był wielokrotnie przez autora eksponowany, zwłaszcza dla podkreślenia niekonsekwencji w działaniu „GW”, chociażby w felietonie Boże, błogosław 
(„Oburza mnie natomiast tak jawnie prezentowana przez publicystę mentalność Kalego - furda prawo, nasi są dobrzy, a tamci to źli faszyści, więc mamy moralne prawo miotać kamieniami”) ${ }^{48}$.

Pewien przełom w obrazowaniu Salonu w felietonach R. Ziemkiewicza można zauważyć w felietonie ze stycznia 2009 r. Dotąd Salon, twierdził felietonista „Rz”, uznawał siebie za jakoby jedyną inteligencję w Polsce. Teraz, w opinii R. Ziemkiewicza, zauważył i dopuścił istnienie innego ośrodka elit intelektualnych. Uzasadniając tę tezę, R. Ziemkiewicz cytował fragment publikacji „GW”, w której środowisko tego dziennika określano mianem „liberalnej inteligencji”49, co zdaniem felietonisty „Rz”, nakazuje myśleć, że autor tekstu uznaje, iż jest jeszcze inteligencja konserwatywna. W mniemaniu R. Ziemkiewicza nastąpiły zatem postęp i zmiana w mentalności środowiska, które do tej pory

paranoików, http://blog.rp.pl/ziemkiewicz/2007/o7/25/boze-blogoslaw-paranoikow-2, 1.05.2010 r., czytamy: „Taki na przykład Lepper, gdy blokował drogi i szturmował urzędy, mógł się wydawać paranoikiem, a dziś coraz liczniejsze grono normalnych skłonnych jest widzieć w nim rozsądnego polityka, w sam raz na partnera do zawarcia konstruktywnych porozumień niezbędnych w celu odsunięcia od władzy paranoików”. W tekście Palikocie, nie jesteś sam, http://blog.rp.pl/ziemkiewicz/2008/10/22/palikocie-nie-jestes-sam, 9.05.2010 r., R. Ziemkiewicz napisał natomiast: „Jest taka gazeta, która na jednej stronie z satysfakcją donosi, iż w Chile skazano za pinochetowskie zbrodnie 88-letniego generała, na drugiej kibicuje Hiszpanom wymawiającym rozejmową zasadę nierozliczania zbrodni generała Franco, a na trzeciej protestuje przeciwko sądzeniu Jaruzelskiego, bo ma 85 lat i oddał władzę bez-krwawo i komu należało. Na czwartej zaś ubliża od najgorszych za zauważenie oczywistego faktu, iż od lat jak może wybiela sprawców stanu wojennego i relatywizuje ich winy". Takich zgrabnie ujętych formuł jest w tekście dokładnie 4. Wyliczone jedna po drugiej, sprawiają wrażenie niekończących się, słusznie stawianych zarzutów. Natomiast w felietonie Kolorowy świat, http://blog. rp.pl/ziemkiewicz/2009/07/28/kolorowy-swiat, 9.05.2010 r., felietonista „Rz” wypowiadał się na temat względności osądów „GW” i jej zmiennych sympatii do aktorów życia publicznego: „wszystko jest względne - Michał Kamiński może być dziś czołgany jako nacjonalista za niegdysiejszą przynależność do ZChN i wyprawę do Pinocheta, a Stefan Niesiołowski, który ZChN zakładał i był jego twarzą, oraz Tomasz Wołek, który wyprawiał się razem z Kamińskim, są spoko-kolesiami i publikują regularnie w $G W^{\text {”. }}$. Zarzucił ponadto Gazecie, że manipuluje i steruje „dystrybucją oburzenia i potępienia”. To właśnie niekonsekwencja stała się podstawą do wyodrębnienia kolejnej grupy argumentów. Jest to technika erystyczna, którą M. Kochan określił jako „szukanie dziury w całym", natomiast A. Schopenhauer jako argumenty ad hominem lub ex concessis, tj. odwołanie się do poglądów rozmówcy (M. Kochan, op. cit. s. 72-82; A. Schopenhauer, op. cit. s. 19). Polega ona na wyszukiwaniu pozornej lub realnej sprzeczności w czyichś poglądach albo działaniach. Następnie sprzeczność wytyka się rozmówcy, usiłując w ten sposób dowieść, że jego poglądy są niesłuszne. Technika ta bazuje na prawidłowości, zgodnie z którą wytknięcie przeciwnikowi niekonsekwencji, braku spójności w działaniu, czy wygłaszanych sądach, obniża jego wiarygodność w oczach widzów.

${ }^{48}$ Ibidem.

${ }^{49}$ R. A. Ziemkiewicz - blog Rzeczpospolitej, List, op. cit. 
nie uznawało istnienia czegokolwiek wartościowego poza koncepcjami swoich zwolenników („To milowy krok do znormalnienia”) ${ }^{50}$. Autor felietonu wyraził wówczas także nadzieję, że „Jeszcze parę lat i może dojdzie do tego, że z niektórymi przedstawicielami «liberalnej inteligencji» zacznie być możliwy merytoryczny, pożyteczny dla debaty publicznej spór" ${ }^{1}$.

\section{WNIOSKI}

ZESTAWIAJĄC ZE SOBĄ TEORIĘ OBIEKTYWIZMU J. Westerstahla oraz liczne definicje, charakteryzujące gatunek dziennikarski, jakim jest felieton, w których zawsze podkreśla się prawo do subiektywizmu i dowolności odautorskiej, stwierdzono że w przypadku tego rodzaju publikacji komentarz jest rzeczą naturalną i spodziewaną. Także R. Ziemkiewicz swoje felietony wykorzystał do prezentacji własnych, często kontrowersyjnych, a nawet nienawistnych poglądów. Przedstawiając „GW”, chętnie wykorzystywał manipulację i perswazję, przy czym manipulacja dominowała nad perswazją. Autor nie stronił od podawania czytelnikom wyrazistych interpretacji, recept i wskazówek odnośnie pojmowania i rozumienia świata, w tym roli jego medialnych adwersarzy, rzadziej natomiast sugerował korzystne dla odbiorcy rozwiązania.

Prymat interpretacji nad doradzaniem stanowi podstawową różnicę między działaniem manipulatywnym i perswazyjnym. Perswazja jest działaniem zorientowanym na odbiorcę, ma na celu mu dopomóc. Natomiast manipulacja to działanie zorientowane na nadawcę, służące jego subiektywnym interesom. Komunikaty manipulatywne często tworzy się przy pomocy przekłamań bądź wyolbrzymień, a także poprzez nadużywanie powszechnie znanych i używanych pojęć. W stosowanej przez Ziemkiewicza argumentacji można wyróżnić kilka elementów niezmiennych, pojawiających się stale na przestrzeni przebadanych dwóch lat. W 24 tekstach pojawiał się nacechowany pejoratywnie podział społeczeństwa na „my - oni”. W 22 R. Ziemkiewicz dyskredytował czołową postać „GW” - redaktora naczelnego A. Michnika, a w 11 operował etykietami. Zgodnie z modelem teorii uczenia, Ziemkiewicz systematycznie usiłował wpoić czytelnikom „Rz” określoną wizję Gazety oraz jej redaktorów i sympatyków. W jego felietonach argumenty ad hominem ${ }^{52}$ dominowaly nad argumentami ad rem $^{53}$.

\footnotetext{
${ }^{50}$ Ibidem.

${ }^{51}$ Ibidem.

${ }^{2}$ A. Schopenhauer, Erystyka..., op. cit. s. 32.

53 Ibidem, s. 19
} 
W badanym okresie styl argumentowania, jakim posługiwał się R. Ziemkiewicz, nie uległ jakiejś wyraźnej, diametralnej zmianie. Felietonista stale odwoływał się do znanych motywów, wrogów i wydarzeń, realizując linię programową „Rz”, a także dyskredytując jej wiodącego oponenta medialnego.

\section{SUMMARY}

EDITORS OF DAILY NEWSPAPERS struggle every day in order to attract readers. It applies especially to opinion newspapers which represent different political views. Two leading newspapers in Poland are "Rzeczpospolita" and "Gazeta Wyborcza". The analysis of articles published in these newspapers shows how journalists are trying to manipulate the readers. The manipulation and persuassion, used by one of the leading commentators from "Rz" - Rafał Ziemkiewicz became the object of this study. Having almost 400 columns of that author's analyzed, it can be stated that in his writings there are elements of both manipulation and persuassion. These elements are divided into thematic groups.

\section{Nota O AUTORCE}

Paulina Piątek [paupiatek@gmail.com] - absolwentka studiów I stopnia na kierunku politologia, specjalność dziennikarstwo Wydziału Nauk Politycznych i Dziennikarstwa UAM w Poznaniu. Obecnie studentka I roku studiów II stopnia, na kierunku politologia, spec. reklama i promocja, przebywająca na wymianie studenckiej na University of Ljubljana w Słowenii. Interesuje się kulturą polityczną oraz językiem dyskursu w mediach. Prywatnie odkrywa tajniki świata radia i telewizji. 
